\title{
Quality of Government and Political Behavior
}

Resignation and Agency

\author{
Mattias Agerberg \\ Department of Political Science \\ University of Gothenburg
}


Doctoral Dissertation in Political Science

Department of Political Science

University of Gothenburg

2019

(C) Mattias Agerberg

Printing: BrandFactory, Kållered, 2019

ISBN: 978-91-7833-514-5 (print)

ISBN: 978-91-7833-515-2 (pdf)

http://hdl.handle.net/2077/61596 (e-pub)

Published articles have been reprinted with permission from the copyright holders.

This study is included as number 162 in the Series Göteborg Studies in Politics, edited by Bo

Rothstein, Department of Political Science, University of Gothenburg. 


\section{Abstract}

Most people in the world live in countries where poor quality of government and corruption are a pressing problem. Research also shows that these are issues that citizens are deeply concerned about. Yet, questions about quality of government and corruption are largely absent in the traditional literature on political attitudes and behavior. This dissertation aims to fill some of the gaps in the previous literature by exploring how poor public institutions structure political life. The dissertation argues that the quality of government crucially affects individuals' relationship to the state and their belief about what can be achieved through the democratic process. The results in three individual research papers highlight many of the adverse effects of corruption on various political outcomes, where corruption often is associated with widespread political resignation. At the same time, the results also show that citizens in settings with high corruption at times show strong agency and try to find ways to express themselves politically, despite the many obstacles to effective political participation that widespread corruption entails. 


\section{Sammanfattning på Svenska}

Majoriteten av världens befolkning lever i länder där korruption och dåligt fungerande offentliga institutioner är problem som präglar deras vardag. Detta inkluderar även innevånare i stater som brukar klassificeras som demokratiska och ekonomiskt utvecklade. Forskning visar att korruption också är något som människor bryr sig om; flera studier visar att korruption hör till de politiska frågor som rankas som viktigast och diskuteras mest världen över. Samtidigt så har frågor om samhällsstyrningens kvalitet (quality of government) och korruption i princip varit frånvarande i den traditionella forskningslitteraturen om politiska attityder och politiskt beteende. Denna avhandling syftar till att fylla delar av denna forskningslucka genom att studera hur dåligt fungerande offentliga institutioner strukturerar människors politiska agerande. Avhandlingen argumenterar för att samhällsstyrningens kvalitet är en fundamental faktor som formar individers förhållande till staten och deras uppfattning om vad som kan åstadkommas genom den demokratiska processen. Resultaten från tre fristående forskningsartiklar belyser flera negativa effekter av korruption på olika politiska utfall, där korruption ofta är associerat med politisk resignation. Samtidigt så visar resultaten att människor som lever i korrupta kontexter uppvisar betydande handlingskraft genom att finna nya vägar till politiskt engagemang, trots det hinder för effektivt politiskt deltagande som korruption utgör. 


\section{Acknowledgements}

Many people have, directly or indirectly, helped and supported me in writing this dissertation.

First of all, I want to thank my supervisors, Lena Wängnerud and Nicholas Charron. Lena supervised my bachelor's thesis back in 2012 and has been an integral part of my academic development ever since. You are both sources of inspiration to me, and have provided encouragement, guidance, and innumerous helpful comments on my work (often on-demand, after I've unannounced sent you my more or less unpolished texts). I look forward to our continued collaboration!

I am especially grateful to all the people at the Quality of Government institute. The QoG institute has always provided an inclusive and inspiring research environment, full of smart, nice, and friendly researchers. These include: Bo Rothstein, Sören Holmberg, Amy Alexander, Monika Bauhr, Frida Boräng, Rasmus Broms, Andreas Bågenholm, Nicholas Charron, Stefan Dahlberg, Carl Dahlström, Victor Lapuente, Marina Nistotskaya, Anna Persson, Lena Wängnerud, Helena Stensöta, Anders Sundell, Elin Bergman, Dragana Davidovic, Stephen Dawson, Marcia Grimes, Aksel Sundström, Marina Povitkina, Aiysha Varraich, and Georgios Xezonakis. The QoG-conferences have always been a high point during the year, where the participants actually read your paper and provide useful feedback (this is an unusual feature for a Political Science conference). A special thanks to Alice Johansson, Tove Wikehult, and Dalila Sabanic for organizing these (and everything else QoG-related). I really hope to continue being part of this great research environment in the future!

Many other colleagues (and visiting researchers) in the Political Science department at GU have made pursuing a $\mathrm{PhD}$ an enjoyable and rewarding experience: Thanks to Peter Esaiasson, Jenny de Fine Licht, Mike Tomz, Andreas Bergh, Jonas Bergan Draege, Lisanne de Blok, Sofia Breitenstein, Jacob Sohlberg, Mikael Gilljam, Henrik Oscarsson, Sofia Axelsson, Elin Naurin, Kristen Kao, Ellen Lust, Sverker Jagers, Ruth Carlitz, Lisbeth Aggestam, Anna Bendz, Ulf Bjereld, Ann-Marie Ekengren, Henrik Friberg-Fernros, Jonas Hinnfors, Andrej Kokkonen, Staffan I Lindberg, Anna Lührmann, Ulrika Möller, Birgitta Niklasson, Jon Pierre, Jonathan Polk, Maria Solevid, Richard Svensson, and Ann Towns. A special thanks to Carl Dahlström and Mikael Persson for their superb management of the PhD program. I also want to thank Maria Lilleste, Lena Caspers, Karin Jorthé, Caroline Fällgren, and Ola Björklund for always solving every weird administrative query I've thrown your way.

I think it's fair to say that the other $\mathrm{PhD}$ students at the department is what has most profoundly shaped me as a researcher. To name some of you: my awesome PhD-cohort, including Anne-Kathrin Kreft (also my coauthor and office mate the past 4 years; thanks for not telling anyone about my e-sport watching habits), Felix Hartmann, Marcus Tannenberg, and Moa Frödin Gruneau. Former PhD students, like Aksel Sundström, Olof Larsson, Anders Sundell, Marina Povitkina, Erik Vestin, Elina Lindgren, Petrus Olander, and Rasmus Broms. And current PhD students, including Love Christensen, Maria Tyberg, Valeriya Mechova, Aiysha Varraich, Elin Bergman, Ezgi, Irgil, Felix Dwinger, Prisca Jöst, Stephen Dawson, Elias Markstedt, Niels Markwat, and Dragana Davidovic. Even though my number of higher education credits is tending to infinity at this point, I've still learned more about doing research from you; during lunches, coffee breaks, seminars, after works, and random joint procrastination sessions. Thank you! Also: you are really nice people and I consider you my friends! 
The arguably most important reason I actually ended up doing a $\mathrm{PhD}$ in Political Science is my old partner in crime Dennis Andersson (I know establishing causality is hard, but of this one I'm sure). After studying the noble topic of Swedish agricultural history together, Dennis decided that we were to study Political Science. As a matter of fact, I wanted to continue to immerse myself in the world of iron plows, but Dennis declared that his decision was final (he was - and still is only a lukewarm supporter of the principles of liberal democracy). In hindsight, I have to concede that this was a good decision. Thank you, Dennis!

Finally, thanks to my family - Marie, Torbjörn, and Malin - for continuous love and support. And thanks to Ellen, my most engaged discussion partner and my best friend. Thanks for all our long dinner talks about politics. I feel that I never managed to actually convince you of anything Political Science-related (I mean come on - show some respect for all my higher education credits!), but I've always felt that you're rooting for me in everything I do. 


\section{Contents}

1 Introduction 1

1.1 A study of quality of government and political behavior . . . . . . . . . . 1

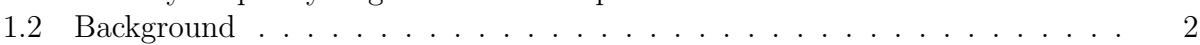

2 Theory 4

2.1 Defining quality of government and corruption . . . . . . . . . . . 4

2.2 QoG in democratic regimes . . . . . . . . . . . . . . 5

2.3 QoG and trust in democratic institutions . . . . . . . . . . . . . . . . 9

2.4 QoG and democratic behavior . . . . . . . . . . . . . . . . 10

2.5 Corruption voting . . . . . . . . . . . . . . . . . . . . . 12

2.6 Democratic actors in a corrupt system . . . . . . . . . . . . . . 13

$\begin{array}{lll}3 & \text { Research design } & 15\end{array}$

3.1 Data . . . . . . . . . . . . . . . . . . . . . 16

3.2 Methods . . . . . . . . . . . . . . . . . . . . . . 17

4 Papers in Brief $\quad 19$

4.1 Paper 1. Failed Expectations: Quality of Government and Support for Populist Parties in Europe . . . . . . . . . . . . . . . . . . . . . 19

4.2 Paper 2. The Curse of Knowledge? Education, Corruption, and Politics . . . 20

4.3 Paper 3. The Lesser Evil? Corruption Voting and the Importance of Clean Alternatives . . . . . . . . . . . . . . . . . . . . 22

5 Conclusions 24

$\begin{array}{lll}6 & \text { Papers I-III } & 36\end{array}$ 


\section{List of Figures}

1 Corruption and level of democracy 


\section{Introduction}

\subsection{A study of quality of government and political behavior}

In the 2010 Brazilian general elections the professional clown Tiririca became the mostvoted-for congressman and was elected to the national Chamber of Deputies (despite some uncertainty as to whether Tiririca actually was literate). The clown-congressman was elected in the wake of several publicized corruption scandals, running on slogans like 'It can't get any worse, vote Tiririca'. After serving 7 years in the Chamber of Deputies, the clown Tiririca announced in December 2017 that he would not run in the upcoming elections, citing that he was too embarrassed by the corruption and incompetence among his politician colleagues (The Economist Dec 14th, 2017).

Most of the world's countries suffer from corruption and poor quality of government (albeit, of course, to different degrees). ${ }^{1}$ My main claim in this dissertation is that this matters for political life and for political behavior among citizens, in ways previously overlooked. As illustrated in the Brazilian example above, big corruption scandals can change the logic of politics and erode peoples' trust in politicians and the political system. At the same time, corruption is also an everyday problem that many citizens face around the world. These more subtle forms of corruption affect how millions of voters perceive the quality of public institutions and the efficiency of the state. In the end, this affects how they behave and think politically.

Traditionally, corruption has not been an important part of the literature on political behavior. This is a significant shortcoming. Given that most people in the world - importantly, including people in mature democracies - live and act in societies where corruption is more or less an ever-present phenomenon, this variable should be taken seriously when thinking about how people engage in politics. In this dissertation I identify three themes, based on a broad reading of previous research, that may serve as a point of departure for researchers thinking about the relationship between corruption/quality of government (QoG) and political behavior. The themes are, in brief: (1) corruption is something that people are deeply concerned about, (2) corruption and QoG shape the relationship between the individual and the state, (3) corruption and QoG affect citizens' belief about the capacity of the democratic state. The insights underlying these themes are under-appreciated in the political behavior-literature and have only recently started to become acknowledged as significant factors shaping indi-

\footnotetext{
${ }^{1}$ I define these terms in section 3.1. In short, I use 'quality of government' as a general concept that captures the quality and functioning of public institutions and the degree to which these institutions operate under the norm of impartiality. I consider 'corruption' to be the most important instance of low quality of government and a strong violation of the norm of impartiality. Corruption in this sense involves a public official exploiting his or her office for personal gain.
} 
viduals' political thinking. I argue that these insights should be incorporated more explicitly in research on topics such as voting behavior and political accountability.

Starting from these themes, the dissertation explores the relationship between corruption and political behavior in three individual research papers. The results show that corruption and quality of government are important variables to consider in models on political attitudes and participation. The dissertation expands on and contributes to previous work on the subject by exploring the relationship between corruption and several political outcomes that are under-researched in this literature, like vote preference and political efficacy. While this highlights the many adverse effects of corruption on political life, the results also provide a more complex view of democratic actors in corrupt systems that is an important contribution to the literature. On the one hand, corruption fosters a sense of political resignation among citizens, where trust in political institutions and the belief in the capacity of the democratic state is significantly weakened. On the other hand, the results also provide an important complementary picture that highlights the agency of citizens in corrupt settings: despite the many obstacles to effective political engagement that widespread corruption entails, citizens try to find ways to express themselves politically. When given the opportunity, many voters will use their democratic power to try to change the system and hold elite political actors accountable. This hence also highlights the potential of political accountability as a means to combat corruption and improve the quality of public institutions.

\subsection{Background}

Before the 1990s researchers paid little attention to the problem of corruption. During the last decades, however, debates on institutions have reached the center stage of academic research and with these debates discussions about governance, quality of government (QoG), and corruption have followed (Rothstein 2011). Today, few scholars of comparative politics would dispute the importance of these issues when it comes to the functioning of society and the well-being of its citizens (Fisman and Golden 2017).

Due to its long-time position in the academic periphery, corruption has not been a part of traditional comparative work on political attitudes and behavior, and only in relatively recent years have researchers started to acknowledge the profound consequences corruption can have for the functioning of democracies (Warren 2004). For it is not the case that corruption is only a problem affecting 'developing' countries. Transparency International estimates that over $80 \%$ of the world's population live in countries where corruption is a very serious problem. ${ }^{2}$ Research shows that startlingly poor public institutions can be

\footnotetext{
${ }^{2}$ The statistic is based on the number of countries that scored less than 50 on the Corruption Perception Index, with 100 being the best possible score.
} 
found, for instance, at the heart of western Europe, in what many consider among the most 'developed' parts of the world (Charron et al. 2013). A growing literature in political science has, in the light of this, started to ask questions about how differences in institutional quality shape and structure citizens' political attitudes and behavior.

While long neglected by academics, the issue of corruption occupies the minds of citizens around the world. When the World Economic Forum recently surveyed individuals between 18 and 35 from 186 countries around the world about most pressing issues of concern in their country 'government accountability and transparency/corruption' ranked 1st, with $46.9 \%$ of the votes globally (World Economic Forum 2017). Other surveys have shown that corruption is the political issue most frequently discussed by the public globally, ahead of topics like extreme poverty, climate change, and terrorism (Holmes 2015). Even in countries where corruption is very widespread, citizens still view bribe payments and the misuse of public money as a serious moral wrong that can not be justified (Karklins 2005; Persson et al. 2013; Rothstein and Varraich 2017). It is hence clear that corruption is not only something that can be shown to substantially affect the functioning of states in a general sense, but also something the citizens are deeply concerned about. This, I argue, gives us strong reasons to consider the political consequences of corruption. We can not fully understand democratic behavior without understanding how the substantial variation in institutional quality affects political life. From a research perspective, this opens up an opportunity to add a valuable contribution to a relatively new (but constantly expanding) research literature. The overarching question for this dissertation can thus be summarized as how does corruption/QoG affect citizens' political attitudes and behavior?

Questions about how corruption relates to political attitudes and behavior inevitably brings us to classic themes in political science, like political trust and voting behavior. However, how corruption is related to these important topics is a largely overlooked topic in the traditional literature. This is obviously partly a result of the general lack of interest in corruption that was ubiquitous in academia until relatively recently, and partly a result of the fact that many influential studies on political behavior and attitudes have mostly been concerned with 'low-corruption contexts' (in a relative sense), like the US or Western Europe (e.g. Campbell et al. 1960; Wolfinger and Rosenstone 1980; Zaller 1992). An interesting exception is the political science classic The Civic Culture by Almond and Verba (1963). The authors study the democratic system and culture (around the year 1960) by surveying about 1000 respondents in each of five countries: the United States, the United Kingdom, Germany, Mexico, and Italy. Mexico and Italy are countries where widespread corruption was (and still is) a major problem. The authors describe respondents in these countries as 'alienated', believing that the government ought to provide services for them, 
but realizing that public institutions are corrupt and responsive only to bribes or family connections. Many interviewees report resignation and cynicism in the face of local public officials pocketing tax money and politicians only catering to the needs of the well-connected (Almond and Verba 1963, pp. 50-51). The authors describe a political culture where a large number of citizens, partly as a result of this, are 'parochial'; political sleepwalkers who feel like strangers in their own society. With slightly more modern terms we might describe these as citizens with low political efficacy and low political trust. These are themes that I will return to many times in this dissertation.

Recent years have seen an increased interest in corruption as a phenomenon that affects political life and electoral politics. In a seminal paper Ferraz and Finan (2008) study the effects on electoral accountability of disclosing information about corruption practices. Using publicly released audit reports, part of a federal anti-corruption program in Brazil, the authors show that the corruption information had a significant impact on incumbents' electoral performance: releasing the reports prior to an election decreased the incumbent's likelihood of reelection by $17 \%$. In another study, Chong et al. (2015) randomly assigned voting precincts to a campaign spreading information on corruption and public expenditure conducted one week before the 2009 municipal elections in Mexico. The authors find that corruption information decreased support for the incumbent party, but also that it decreased support for the challenger party, decreased voter turnout, and eroded partisan attachments. These two studies show that corruption can have very real consequences for politics and democratic behavior. At the same time, the studies also suggest that the effects are complex and sometimes unpredictable. Despite the recent growing interest in the relationship between corruption and political attitudes and behavior, we still have just scratched the surface; there still exists major research gaps with regard to how, when, and why corruption affects politics. My hope is that this dissertation will provide a valuable piece to this burgeoning research area, and make an important contribution to both the corruption literature and the literature on comparative political behavior.

\section{Theory}

\subsection{Defining quality of government and corruption}

Before delving deeper into the literature on corruption and different aspects of political behavior I first provide some general definitions.

The academic debate on related concepts like 'governance', 'corruption', and 'quality of government' reaches back several decades. While much ink has been spilled, there still exists 
a number of different definitions and conceptualizations with regard to these terms (Agnafors 2013; Fukuyama 2013, 2016; Rose-Ackerman 1999, 2017; Rothstein and Teorell 2008). The central goal of this dissertation is not to advance this theoretical debate. However, a few general definitions are warranted. I use 'quality of government' (QoG) as a general concept that captures the quality and functioning of public institutions. I draw upon the discussion in Rothstein and Teorell (2008, p. 170) and define high quality of government (or 'good government/governance') as impartiality. In this definition, the principle of impartiality is a procedural norm where government officials who implement laws or policies do not take anything into consideration about the citizen that is not stipulated by the law or policy beforehand. I consider corruption to be a very strong and serious violation of this principle; Rothstein (2014) has even argued that corruption should be considered the opposite of impartiality. Corruption can broadly be defined as an act involving a public official who exploits his or her office to further his or her personal interests - rather than the public's. ${ }^{3}$ Corruption, according to this definition, involves things like a politician accepting or extorting cash bribes, assigning contracts to family members (the latter a more indirect form of 'personal interest'), or engaging in outright theft and embezzlement. It also includes 'petty' forms of corruption, where, for instance, bureaucrats or civil servants illegally increase their salaries by extracting bribes (and thereby violate the norm of impartiality) (Fisman and Golden 2017, pp. 23-55).

In this sense, 'quality of government' is a higher level of abstraction than 'corruption'. I find the former term useful when talking about the functioning of societies in a more general sense. Corruption moves us one step down the ladder of abstraction (Sartori 1970), focusing on the most important instance of low quality of government. The individual papers in the dissertation focus on slightly different aspects of QoG and corruption to provide the most relevant level of operationalization for the specific research question at hand. For instance, in paper 3 I focus on political corruption specifically, moving one step further down the ladder by studying a specific type of corruption. Paper 1, on the other hand, uses a much more general level of operationalization that is closer to the broad concept of QoG. I provide additional clarifications and definitions when necessary in each individual paper.

\subsection{QoG in democratic regimes}

Is poor quality of government and corruption a problem in democracies? Certainly, the worst offenders on Transparency International's Corruption Perceptions Index are not famous for their civil liberties and democratic freedom; countries like North Korea and Somalia are

\footnotetext{
${ }^{3}$ See also https://www.transparency.org/what-is-corruption
} 
repeatedly ranked among the most corrupt in the world (Fisman and Golden 2017, ch. 3). Given that corruption is most commonly associated with poor autocratic regimes, is the phenomenon an interesting factor to study and consider in democratic contexts?

A common assumption is that democratic institutions is an antidote for corruption. Competitive elections should, in theory, work as a powerful means for aligning policy making with the public interest. And as convincingly shown by research from recent decades, good government is undeniably in the public interest. Moreover, given citizens' strong distaste for corruption, electoral competition should give political candidates a strong incentive to stay away from corrupt dealings. Therefore, it is not unreasonable to expect relatively wellfunctioning democracies to be more or less free from corruption.

Unfortunately, reality is far more complex. Several studies have shown that the relationship between quality of government and level of democracy at the macro-level by no means is a straightforward linear relationship; more democratic countries are simply not always less corrupt (Bäck and Hadenius 2008; Charron and Lapuente 2010; Keefer 2007; Sung 2004).

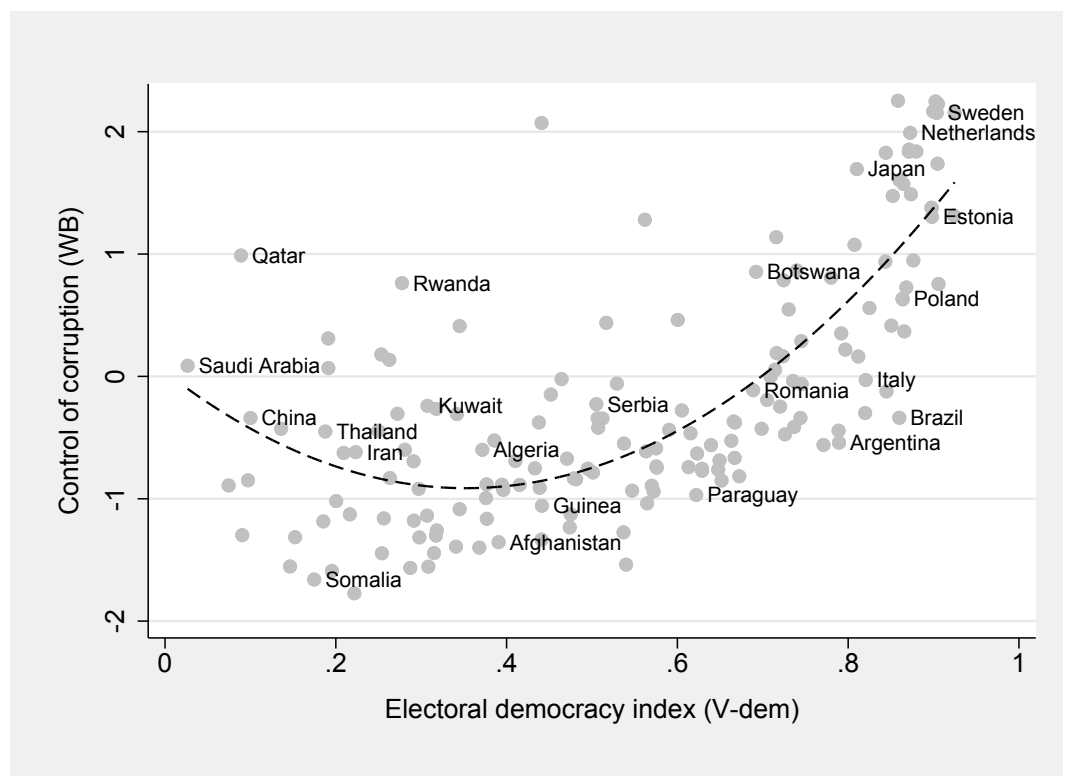

Figure 1: Corruption and level of democracy. The y-axis displays different countries' score on the World Bank's Control of corruption index. The x-axis shows the score for different countries on the V-dem's Polyarchy index, indicating the level of 'electoral democracy'.

Figure 1 plots the World Bank's Control of corruption index ${ }^{4}$ (y-axis) against the V-dem's

\footnotetext{
${ }^{4}$ Kaufmann et al. (2011)
} 
Polyarchy index ${ }^{5}$ (x-axis). Eyeballing the graph, it is quite remarkable that deeply authoritarian states, like Saudi Arabia and Qatar, actually perform better in terms of controlling corruption than democratic states like Italy and Brazil.

The point of departure in this dissertation is that many (even most) democratic countries suffer from problems with corruption and poor QoG (needless to say, to different degrees). That is, it is possible for a country to in general adhere to the principles of electoral democracy - and be classified as a 'democracy' in all reasonable categorizations - and still struggle with poorly working and corrupt public institutions. The group of countries classified as 'free' by the Freedom House ${ }^{6}$ has an average score of 57 (with a median score of 55) on Transparency International's corruption perceptions index ${ }^{7}$. The index, ranging from 0 (highly corrupt) to 100 (highly clean), thus suggests that many democratic countries are only average performers when it comes to control of corruption.

Even within the EU, arguably among the most democratic and developed parts of the world, corruption and low QoG are highly prevalent issues. Charron et al. (2014) notice great variation in QoG not only between countries in the European Union, but also within single countries. For instance, most regions in northern Italy perform well in terms of QoG almost on par with known high-performers like Denmark. At the same time, several regions in southern Italy suffer from widespread corruption on a level commonly associated with poor developing countries. The empirical evidence is thus clear: corruption is a serious problem in many democracies, and no democratic country (or non-democratic, for that matter) can claim to be completely 'corruption-free'. The fact that corruption is a present problem in most democratic countries gives us strong reasons to consider how this variable relates to models of democratic behavior among citizens.

How much does a country's level of corruption matter overall? Early research often focused on the potential upsides of corruption; as a way of getting around cumbersome and unnecessary rules and regulation and thereby reducing inefficiencies in the political system (e.g. Huntington 1968). These ideas have fallen out of fashion in the face of mounting empirical evidence of how corruption actually affects societies. An emerging consensus is that the effects of corruption are corrosive, without any side-benefits to society as a whole: corruption impairs economic growth (Mauro 1995; Rose-Ackerman 1999), increases economic inequality (Gupta et al. 2007; You and Khagram 2005), creates inefficiencies in public service delivery (Bardhan 1997; Olken and Pande 2007), and is in general negatively associated to a wide range of indicators of human welfare (Fisman and Golden 2017; Holmberg and Rothstein

\footnotetext{
${ }^{5}$ The index measures the extent to which "... the ideal of electoral democracy in its fullest sense [is] achieved" (see Coppedge et al. 2016)

${ }^{6}$ https://freedomhouse.org/report/freedom-world/freedom-world-2018

${ }^{7}$ https://www.transparency.org/research/cpi/overview
} 
2011; Holmberg et al. 2009).

Researchers have also in recent years started to acknowledge the relationship between poor QoG and the workings of democracy in general. Why should we expect poor QoG and corruption to be related to aspects of the functioning of democracy specifically? Warren (2004, 2006) argues that corruption corrodes the meanings and mechanisms of democracy itself. By breaking the link between collective decision-making and peoples' power to influence these decisions, corruption reduces the effective domain of public action and the reach of democracy. This, according to Warren, violates one of the central principles of democracy, namely the principle of inclusion - the norm that every individual potentially affected by a collective decision should have an opportunity to affect the decision proportional to his or her stake in the outcome (Warren 2006, p. 804). Corruption thus involves unjustifiable exclusion: The corrupt use their control over resources to change public agencies into instruments of private benefit, at the expense of people excluded from the corrupt transaction. In this sense, what is corrupted is "government as the trustee and executor of collective purposes"; a collective agent that people can trust to execute collective decisions. Warren refers to this as the corruption of democracy by duplicitous exclusion (Warren 2004). When people lose faith that public decision are taken for reasons that are publicly available and justifiable, they can be expected to become cynical about politics and passive democratic citizens.

While much research on political attitudes and behavior in democracies traditionally have focused on factors on the input side of politics, corruption and QoG are better viewed as factors on the output side (see Easton (1953)). Factors on the input side are related to the process of translating public opinion to political decisions and the different institutional arrangements involved in this process. For instance, the traditional literature on the determinants of voter turnout has mostly been focused on individual-level factors, like education, and institutional input side factors like electoral rules and party systems (see Blais 2006).

Focusing on output side factors implies a slightly different perspective, notably that the ultimate proof of the pudding must be in the eating. This perspective emphasizes the importance of what citizens actually get in the end; how policies are implemented, and the way in which public services are delivered. Needless to say, this is not to claim that input factors are not important in shaping political attitudes and behavior. Rather, it is the view that output factors are often at least as important, and that they sometimes can be absolutely crucial for understanding many important questions in political science.

Building on this discussion about the effect of corruption in democracies I will now briefly review three topics of central interest to this dissertation, all related to the overall question about the relationship between corruption and citizens' political attitudes and behavior: QoG and trust in democratic institutions, QoG and democratic behavior, and corruption voting. 


\subsection{QoG and trust in democratic institutions}

Questions about QoG and trust in democratic institutions are part of the larger literature on determinants of system support. In his seminal paper, Easton (1975) distinguishes between specific and diffuse support. Specific support is directed towards the political authorities and authoritative institutions, and is therefore closely tied to current regime performance. For instance, an economic downturn might strongly affect citizens' specific support when they perceive that the incumbents have mismanaged the economy. Diffuse support, on the other hand, tends to be more durable and persistent. This more abstract kind of support is tied to the political regime as a whole, rather than to specific actors. Easton identifies two core components of diffuse support: trust and legitimacy. Trust in this sense can be described as a feeling that the political system would produce preferred outcomes even if left unattended. Legitimacy is defined as a conviction that it is 'right and proper' to accept and obey authorities in the political sphere, and that these authorities, in some general sense, conform to citizens' own moral principles Easton (1975, pp. 447-451).

Research has established a strong empirical link between QoG and diffuse support. Persistent and widespread corruption is closely connected to low trust in the political system and low faith in democratic institutions. In one of the early studies exploring this link, Seligson (2002) conducted a nationally representative survey in four Latin American countries to test the effect of corruption experiences on belief in the legitimacy of the political system. The author finds a strong negative relationship in all four countries. In a related study, Anderson and Tverdova (2003) analyze data from the International Social Survey Program and find that citizens in countries with higher corruption (as measured with Transparency International's CPI index) express more negative evaluations of the political system and exhibit lower trust in civil servants. Similar findings are reported by Wagner et al. (2009) who analyze how institutional factors affect satisfaction with democracy. Using Eurobarometer data in a longitudinal study of European countries over the years 1990-2000 the authors find that high quality institutions like the rule of law and low corruption seem to have a positive impact on average satisfaction with democracy. Several other studies support this conclusion; empirically, the link between QoG and trust in democratic institutions is thus well-established in the literature (see Dahlberg and Holmberg 2014; Dahlberg et al. 2015; Gilley 2006; Mishler and Rose 2001).

It is easy to see why publicized political corruption scandals might erode citizens' trust in the political system. But the empirical evidence suggests that also experience with more petty forms of corruption (for instance, in everyday encounters with public officials) is related to political trust and legitimacy. Rothstein (2009, p. 325) argues that this is not surprising: 
It is the absence of corruption, discrimination, and similar violations of the principle of impartiality in exercising political power that serves to create political legitimacy. The manner in which public administrations are organized is not just a question of economic rationality and administrative efficiency. In addition, citizens seem to have strong norms about what to expect when they encounter government officials that implement public policies. This argument is built on the fact that citizens generally come into contact with the output side of the political system - with the administration, that is - far more frequently and intensively than they do with its input side. Moreover, what happens to them on the output side is often of crucial importance for their well-being. One could say that the public administration is the political system - as citizens concretely encounter and experience it.

While most empirical studies of the link between QoG and trust in democratic institutions are observational studies, I think we have reasons (both empirical and theoretical) to believe that corruption might be a cause of low diffuse system support. However, we know less about the consequences of this for the functioning of democracy writ large; for instance, what implications does the link between QoG and trust in democratic institutions have for citizens' democratic behavior?

\subsection{QoG and democratic behavior}

The most well-studied aspect of democratic behavior in relation to QoG is the association between corruption and voter turnout. Stockemer et al. (2013) represent the majority view among these studies arguing that as citizens' perception of corruption increases, the percentage of voters who go to the polls in national legislative elections decreases. The authors argue (in line with the review in the previous section) that corruption erodes political trust and lowers citizens' satisfaction with the functioning of democracy. This creates apathetic and alienated voters that are unlikely to be engaged in the political process. This finding is supported by Kostadinova (2003) in a study of voter turnout dynamics in post-communist Europe, where corruption levels in general are high. In line with this, Simpser (2005) finds perceived corruption to be negatively related to voter turnout in both democracies and more autocratic countries. Similar empirical patterns are found in Dahlberg and Solevid (2016), McCann and Domínguez (1998), and Sundström and Stockemer (2015).

In contrast to this, some studies argue that corruption instead might increase voter turnout. Given that voters have a strong preference for low corruption and clean government, widespread abuse of public office might trigger voters to turn out in greater numbers and demand accountability. That is, dissatisfaction might generate a demand for change, which in turn mobilizes citizens to engage in politics (Ezrow and Xezonakis 2014). Studying gubernatorial elections in US between 1975 and 2005 Escaleras et al. (2012) find evidence 
that corruption raises average voter turnout. In an analysis of elections of county supervisors in Mississippi Karahan et al. (2006) find that more citizens voted in counties where supervisor corruption was exposed.

However, as Kostadinova (2009) notes, while corruption initially may mobilize voters to turn out and throw corrupt politicians out of office, systemic corruption is unlikely to have this effect. When voters realize that widespread corruption is 'institutionalized', and something that is unlikely to be affected by the democratic process in the short term, they are instead likely to feel resignation (Bauhr and Grimes 2014). This process will in general depress voter turnout. As noted in the introduction, decreased levels of turnout is also one of the main findings in Chong et al. (2015), where the authors randomly assigned voting precincts to an information campaign about rising levels of corruption.

We know much less about how corruption is related to other forms of political behavior. In a study of central and eastern European countries Hooghe and Quintelier (2014) find that corruption and low QoG is negatively associated with both institutionalized political behavior (like voting) and non-institutionalized political behavior (like protests and demonstrations). However, there exists no consensus with regard to the dynamics between QoG and these more unconventional forms of political behavior. Other studies suggest that widespread corruption instead might increase non-institutionalized political participation (Gingerich 2009; McCann and Domínguez 1998). When institutions are weak, individuals might view protests and demonstrations as their only way of challenging the status quo and express their discontent (Machado et al. 2011; Scartascini and Tommasi 2012).

We thus know relatively little about how the political behavior of individuals is shaped by QoG. While the negative relationship between QoG and voter turnout is relatively well established, how citizens who actually do vote in a high-corruption context differ from voters in low-corruption contexts is still an open question. A recent study suggests that questions like this are worthwhile exploring: Using data from ninety-seven elections, Burlacu (2018) shows that corruption is negatively related to ideological voting. The author argues that corruption makes voters consider ideology less in their voting decisions, partly due to difficulties in identifying parties' ideological positions in high-corruption contexts, and partly due to skepticism about parties ability to actually implement their programs when corruption is widespread. This result is interesting and suggests that corruption might have more far-reaching consequences for political behavior than previously assumed in the literature. 


\subsection{Corruption voting}

A related strand of research focuses directly on corruption as an electoral issue; can political corruption decide elections? To what extent do politicians who engage in corruption get punished and how do voters weigh such behavior against other issues? This is often referred to as corruption voting.

As noted above, studies have demonstrated that information about corruption among politicians can have substantial consequences for electoral outcomes (Ferraz and Finan 2008). At the same time, many studies have shown that the electoral price paid by politicians involved in corruption scandals often is low (or even zero). This means that corrupt politicians often get reelected (Bågenholm 2013; de Sousa and Moriconi 2013; Welch and Hibbing 1997). This is a surprising finding, given voters' strong distaste for corruption, and given the fact that voters view elected representatives as one of the major sources of corruption in society (Global Corruption Barometer 2017).

Understanding corruption voting is central to understanding how QoG shapes citizens' political attitudes and behavior. Ferraz and Finan (2008) show that corruption substantially hurt the incumbent's prospect for reelection in the 2004 Brazilian municipal elections. They also estimate that the effect was most pronounced in municipalities where local radio was present to disseminate the corruption information. Several authors argue that this is the key to understanding corruption voting; voters might often simply not be aware of corrupt activities. Actors involved in corrupt dealings have a strong incentive to hide these activities - they are, after all, illegal - and might try to influence media to not report on corruption. Rebecca Weitz-Shapiro and Matthew S. Winters have shown, in several survey experiments conducted in Brazil, that information can play a critical role in voters' ability to punish corruption (Weitz-Shapiro and Winters 2017; Winters and Weitz-Shapiro 2013, 2016). When given sufficiently specific and credible information about corruption, respondents in their experiments were unlikely to express support for corrupt politicians. This suggests that citizens' lack of information might be an important part of explaining why corrupt politicians get reelected (see also Chang et al. (2010)).

Yet, evidence also suggests that voters sometimes knowingly support politicians involved with corruption. Anduiza et al. (2013), argue, based on evidence from a survey experiment conducted in Spain, that partisan bias can make a voter evaluate the same act as less corrupt when the accused represents the voter's preferred party. This might lead voters to excuse political candidates for corruption, as long as the candidate belongs to the voter's in-group (Solaz et al. 2018).

Another argument holds that voters sometimes find it rational to support a corrupt politician, even in the light of sufficient information about the corrupt act. Rundquist et al. 
(1977) argue that while voters in general have a strong distaste for corruption, they might still feel that other things outweigh the importance of honesty and integrity in government. In this sense, voters 'trade' corruption for other things they like and prioritize. This might be things like economic performance and political competence (Choi and Woo 2010; Munoz et al. 2016; Zechmeister and Zizumbo-Colunga 2013), ideology or issue positions (Peters and Welch 1980; Rundquist et al. 1977; Welch and Hibbing 1997), or more tangible benefits like tax cuts and public projects in the voter's area (Fernandez-Vazquez et al. 2016; Konstantinidis and Xezonakis 2013; Manzetti and Wilson 2007).

In sum, there is a very lively ongoing research debate about the reasons for why voters might tolerate political corruption, and to what extent this occurs. As suggested by the review above, this is also a research topic where there are still important disagreements among researchers. The topic is interesting because it says something about the potential of democracy to improve institutional quality. In theory, free and fair elections give citizens an opportunity to use their political power to 'throw the rascals out', demand accountability, and improve QoG (Adsera et al. 2003). However, the research on corruption voting tells us that this relationship of political accountability might be far more complex than democratic theory predicts.

\subsection{Democratic actors in a corrupt system}

To return to the overarching question of the dissertation posed in the introduction: how does corruption/QoG affect citizens' political attitudes and behavior? The theory section and the reviews above suggest that there are many potential answers to this question. At the same time, three themes emerge in studies on QoG and different aspects of politics. I argue that these themes are a natural point of departure for understanding the role that QoG and corruption play in shaping political behavior, and that they can help us understand how a democratic context with high corruption differs from a democratic context with low corruption.

The first theme is that people care about corruption. Corruption and poor QoG are very concrete problems affecting millions of citizens in democracies around the world. As noted above, these are also issues that people discuss and consistently rank among the most severe problems facing their country (Holmes 2015; World Economic Forum 2017). Even in countries where corruption is widespread, citizens show a strong distaste for corrupt practices and view it as something unjustifiable (Karklins 2005; Persson et al. 2013; Rothstein and Varraich 2017).

The second theme can be summarized as follows: QoG and corruption shape the relation- 
ship between the individual and the democratic state. As shown in the review of the literature on QoG and trust, high corruption is consistently associated with low trust in democratic institutions, low political legitimacy, and low satisfaction with the way democracy works. Consequently, QoG can make or break the individual's belief that public institutions are fair and just, and that they will produce preferred outcomes in the long run. In this sense, QoG is crucial for building the type of diffuse support that is needed for any democratic system to be durable (Easton 1975). Without QoG, citizens might even question whether a liberal democratic state is actually superior to other alternatives.

The third theme is related to what can be achieved by politics: QoG and corruption affect citizens' belief about the capacity of the democratic state. As Warren (2004) notes, corruption in part breaks the link between collective decision making and people's powers to influence collective decisions through participation in politics. This hence constitutes a form of disempowerment of the electorate. When people see that policies are implemented in an arbitrary manner, or that politicians are unjustly influenced by bribes and special interests, they will lose faith in their own ability to affect society by democratic means, and in the capacity of the democratic state.

When corruption is high, previous research thus indicates that people feel alienated from politics and from the policy-making process, with low expectations about what the democratic state can do for them. These relationships are by now fairly well-established in the literature. This dissertation will contribute to the literature by going beyond these basic findings and consider the broader implications of corruption for politics. This involves exploring several more concrete sub-questions that all are related to the overarching research question of the dissertation. These include: Q1. How are citizens' vote choice affected by the level of corruption in society? Q2. How is corruption related to different forms of political participation? Q3. When do citizens punish politicians for involvement with corruption? All these questions point to gaps in the literature. That is not to say that these questions have not been considered by previous research, but rather that the questions are under-explored in general and that no consensus has emerged around potential answers. The first research paper in the dissertation, on QoG and support for populist parties (Agerberg 2017), most directly addresses $\boldsymbol{Q} \mathbf{1}$. $\boldsymbol{Q} 2$ is mainly addressed in the second paper on education, corruption, and politics (Agerberg 2019a), whereas the last paper of the dissertation, on corruption voting and political alternatives (Agerberg 2019b), revolves around Q3. I will return to these three research questions in the conclusions section.

Studying these questions naturally calls for a comparative approach, where QoG is treated as a contextual variable. Individuals are in this case thought of as being situated in a certain context with a certain level of QoG. 'Context' might, for instance, be measured 
and conceptualized at the national or regional level in such a model. A complementary approach is to focus on one specific context and try to think about individual-level variation in perceived QoG and corruption. For instance, some individuals in a specific region might have an encounter with public services where they had to pay a bribe, while other individuals in the same region had no such experience. Or, for some individuals it might be the case that their favorite political candidate suddenly stand accused of corruption, while the preferred candidates of other individuals in the same election had no corruption accusation directed at them.

In his famous model of the political system David Easton described how several factors, like political input and output, interact to shape political decisions, policy, and public opinion (Easton 1953). I think this framework is useful to illustrate how I view QoG as a variable shaping individual political behavior on a general level. In his original model, Easton splits political inputs into two parts: demands (as expressed by the electorate; for instance by voting or protesting) and support (which, in turn, can be divided into diffuse and specific support). The political system responds to political input and generates political output in terms of policy and political decisions. The political output then interacts with society and institutions and produces outcomes, i.e. societal changes that citizens experience (the 'output side' of politics (Dahlberg and Holmberg 2014; Rothstein 2009)). These outcomes, in turn, might generate new demands and behavior on the political input side, resulting in a never-ending cycle. My general argument can be viewed as an extension of this model, stating that QoG fundamentally shapes the way in which political output translates into political outcomes. This extended model explains how similar political output (e.g. similar policies) can have very different effects on the public's demands and support, depending on QoG. QoG, as discussed above, refers to the way in which policies are implemented; whether or not laws or policies are implemented in an impartial manner (Rothstein and Teorell 2008). That is, corruption in the implementation of policy and the general quality of public services is expected to influence how political output is translated into political outcomes that in turn affects the political input stage. All research questions in the dissertation hence revolve around how QoG influences this feedback relationship.

\section{Research design}

In this section I will provide a general discussion on the data and methods that are used in the research papers in the dissertation. A more detailed discussion of the specific data and methods is provided in the individual articles. 


\subsection{Data}

Due to the long tradition of survey research in political science, vast swaths of data on political attitudes and behavior have been collected and analyzed since more than half a century. While there of course exist plenty of methodological debates about the operationalization and measurement of concepts in the study of political behavior, many survey items used to capture how citizens think and act politically are by now well-established. I will discuss the specific measures of political attitudes and behavior that I use in more detail in each individual paper.

On the other hand, measuring corruption (and QoG) is arguably more difficult ${ }^{8}$ Corrup- $^{-}$ tion researchers face a natural obstacle in that corrupt transactions are illegal and therefore conducted in secret. Corrupt officials develop intricate methods to hide their shady dealings from outsiders. A reasonable question is thus whether it is at all possible to obtain meaningful data on the phenomenon? Still, to answer questions about how corruption relates to politics (and other questions about corruption as well) we need to be able to be able to measure the concept. Three commonly used methods to try to assess the scale of corruption are official statistics, perceptual surveys, and experiential surveys (Holmes 2015). Official statistics might seem like a natural starting point; legal statistics typically report things like the number of cases where corruption was investigated and prosecuted. However, official statistics on corruption are notoriously unreliable and problematic. In short, these statistics say more about the independence of the judiciary than actual levels of corruption. It is often the case that where corruption is the most widespread, the judiciary is least likely to have the independence to investigate government officials (Fisman and Golden 2017).

In the light of this, most existing measures of corruption are indirect. To quantify corruption in this dissertation I mainly rely on indirect measures based on data from perceptual and experiential surveys. The most frequently cited source on the scale of corruption worldwide is a perception-based measure compiled by Transparency International (TI) called CPI (Corruption Perceptions Index). The CPI combines surveys of mainly business people and experts and their assessments of the level of corruption in a country. Based on these data TI releases a standardized measure annually that includes most of the world's countries and their level of corruption. Other expert-based measures include the V-dem data that rates countries on a wide range of different aspects like level of democracy, bureaucratic corruption, and press freedom (Coppedge et al. 2016). Perception-based measures like these are quite naturally open to criticism: what exactly drives experts' perception of corruption in a country? Maybe a big crackdown puts bribery in the headlines, even while actual corruption

${ }^{8}$ This section discusses the measurement of corruption specifically, while a discussion on the measurement of QoG more generally can be found in paper 1 (Agerberg 2017). 
is on the decline? Also, these measures only capture the perceptions of certain elite actors and not the general public.

The last point is particularly important in a dissertation trying to analyze how ordinary citizens behave politically. To get closer to how the public experience corruption researchers use experiential surveys. In these, respondents are asked directly about their actual experience with corruption in society. A typical question is: "Have you or anyone in your household been asked to pay a bribe in the last twelve months?". There are, of course, problems with these kind of surveys as well. For one, admitting to paying a bribe might be sensitive information that people are unwilling to disclose. Still, in the 2014 Eurobarometer on corruption 25 percent of Romanians reported that they had been asked to pay a bribe (Eurobarometer 2014). This indicates that many respondents in fact are willing to report their corruption experiences.

There are hence different pros and cons of using perceptual and experiential surveys respectively. A reasonable approach is to be flexible and somewhat opportunistic and try to pick the best measure for the particular study at hand. More importantly, combining and comparing different measures is a good strategy given the varying strengths and weaknesses of different methods; a result that holds up under several different measurement approaches should be viewed as more robust. This is the strategy that I employ in the first two articles in the dissertation. The specific measures that I use are described in the individual papers.

\subsection{Methods}

Much empirical research on corruption has been concerned with mapping the relationship between corruption and different individual and societal outcomes that we care about (like economic growth and life expectancy). This is valuable research: we need to know the correlates of corruption and QoG to start to develop theories about, for instance, how to launch an effective anti-corruption campaign or how much voter turnout decreases when corruption in society goes up. Improved computing power has made it more feasible to fit complex statistical models to large datasets, which in turn has facilitated research with individual-level survey data from multiple countries. In line with this, the first two papers in the dissertation both make use of large multi-country surveys and different statistical modeling techniques.

The advantage of this approach is the scope of the studies. Paper 1 covers most countries in Europe with high-quality data on three different levels: the individual level, the regional level, and the country-level. Paper 2 involves country-representative samples from 31 different democracies. Statistical techniques such as multilevel modeling allows me to estimate 
how different data-levels interact. For instance, in the paper 2 I test how the well-known association between education and political participation (an individual-level relationship) is moderated by the level of corruption in society (a country-level variable). The drawback with this approach is the reliance on observational data. In the absence of a credible natural experiment this makes causal inference very hard. Strong assumptions are generally needed if we want to claim that the associations we observe with observational data are in fact causal. I do not claim that providing any precise causal estimate is the main point of paper 1 or 2. Rather, I think that the robust patterns I observe in the data are interesting in their own right, especially in the light of previous research. I think the evidence in favor of a causal interpretation of these patterns should be viewed as suggestive. I elaborate on these issues in the individual papers.

Paper 3 tackles the issue of causality (with regard to a specific research question) by deploying a survey experiment. Survey experiments have increased in popularity in corruption research over recent years, primarily in the study of corruption voting (the topic for paper 3). ${ }^{9}$ The obvious advantage with this method is randomization of treatment assignment which, in turn, makes causal inference possible (Morgan and Winship 2014). The experiment can be tailored to answer a specific research question and the data can usually be analyzed using relatively simple statistical techniques. Big online platforms for 'survey workers' have also significantly decreased the cost of running experimental studies (Berinsky et al. 2012). There are of course many drawbacks with survey experiments as well, and I discuss some of these issues in paper 3 .

I think paper 3, together with previously mentioned experimental papers, shows that survey experiments have great potential in corruption research. Moreover, several large recent projects have designed impressive field experiments to study questions related to political accountability and corruption (see, for instance, Dunning et al. (2019)). Currently, experimental research is only a limited part of the research area. To overcome issues of causality - one of the main challenges for corruption research as of today - I think the use of these designs need to expand, together with an increased attention to causal identification in general (Keele 2015).

\footnotetext{
${ }^{9}$ Recent examples include Anduiza et al. (2013), Fernandez-Vazquez et al. (2016), Konstantinidis and Xezonakis (2013), Weitz-Shapiro and Winters (2017), and Winters and Weitz-Shapiro (2013, 2016).
} 


\section{Papers in Brief}

\subsection{Paper 1. Failed Expectations: Quality of Government and Support for Populist Parties in Europe}

The first research paper in the dissertation (Agerberg (2017)) is concerned with the question of how citizens' vote choice is affected by the level of corruption in society $(\boldsymbol{Q 1})$. Previous research has shown that perceptions of poor QoG is consistently linked to vote abstention (Kostadinova 2009; Stockemer et al. 2013; Sundström and Stockemer 2015). However, we know much less about how perceptions of QoG affect the people who actually do vote. Paper 1 explores one previously under-explored aspect of this question, namely the relationship between QoG and support for populist parties.

Previous studies connecting corruption to the support for populist parties have mostly relied on broad national-level corruption measures, like the CPI (Hanley and Sikk 2016; van Kessel 2015). These studies have not sufficiently theorized the individual-level mechanisms that drive the relationship, and because of the reliance of national-level measures, previous research have not accounted for the substantial sub-national variation that exists both with regard to QoG and populist support. Drawing upon research on the political consequences of personal experience with state institutions (Kumlin 2004; Rothstein 2009), I propose two different individual-level mechanisms linking QoG to populist support. First, I argue that people directly experiencing poorly functioning state institutions are more likely to view QoG as a salient issue (Klasnja et al. 2016). For these voters, populist parties increase the supply of political alternatives: using data from Bågenholm (2013) and the 2014 Chapel Hill Expert Survey (Bakker et al. 2015) I show that populist parties are substantially more prone to politicize corruption. Second, a large body of research has shown that QoG is strongly negatively related to citizens' political trust (e.g. Anderson and Tverdova 2003; Dahlberg and Holmberg 2014; Seligson 2002). Several studies have also linked low political trust to populist support (e.g. Hooghe et al. 2011; Pauwels 2014). I thus argue that low political trust resulting from poor experience with state institutions makes citizens more susceptible to the strong anti-establishment message of populist parties, that directly caters to peoples' dissatisfaction with how the current political system works.

A large dataset from the Quality of Government institute ${ }^{10}$ on regional-level perceptions of QoG allows me to capture European citizens' perception of QoG in their area, as well as their party preference. This hence opens up the possibility to disaggregate the relationship between QoG and populist support, both to the individual and the regional level. In several

\footnotetext{
${ }^{10}$ qog.pol.gu.se
} 
different individual-level models, using a wide range of techniques to account for confounding variables, I find a robust link between between perceptions of low QoG and intentions to vote for a populist party (as defined by van Kessel (2015)). Using an aggregated version of the QoG measure, I also estimate the relationship between regional QoG and the actual regional vote share of populist parties in recent national elections. The results show that the variables are strongly related, also at this level of analysis: populist parties are in general much more successful in regions with poor QoG, even when holding country-level factors constant.

Paper 1 contributes both to the literature on QoG and to the literature on the support for populist parties. Where previous studies have linked corruption to low voter turnout, the results in the paper suggest that low QoG potentially not only affects whether or not people vote, but also how they vote. With regard to the literature on populism the paper provides a more nuanced argument for the link between corruption and populist support, suggesting two plausible micro-mechanisms behind the relationship.

\subsection{Paper 2. The Curse of Knowledge? Education, Corruption, and Politics}

The second paper (Agerberg (2019a)) explores the second sub-question stated above: How is corruption related to different forms of political participation? The paper departs from one of the most consistent associations in political science: the positive relationship between individual education and various desirable outcomes, like political participation (Persson 2015). I argue that one largely overlooked factor in the literature is how institutional quality affects this relationship. Given the substantial variation in QoG that exists both within, and between, the world's democracies, this is something that needs to be accounted for to fully understand the relationship. ${ }^{11}$

Paper 2 develops the argument that the highly educated are likely to be particularly affected when institutions are weak. While previous research has shown that the educated in democracies have have high institutional trust (Curini et al. 2012), high political efficacy (Jackson 1995), and high rates of political participation (Verba et al. 1995), I argue that institutional quality should be expected to alter these relationships. Research shows that citizens with high education in societies with low QoG in general are more well-informed about deficiencies of public institutions (Hakhverdian and Mayne 2012; Seligson 2002), react more strongly to corruption (Anduiza et al. 2013), and are likely to have experienced high exposure to corruption in the system of higher education (Botero et al. 2013). In contexts

\footnotetext{
${ }^{11}$ For a related argument about the highly educated in authoritarian regimes, see Croke et al. (2016).
} 
where corruption is pervasive and policy implementation is distorted by corrupt public officials (Warren 2004), being highly educated and politically sophisticated will not translate into high institutional trust and a feeling that one can affect political outcomes by using established political channels.

The paper distinguishes between self-regarding attitudes, including indicators like internal political efficacy and political interest, and institutional attitudes, including indicators like external political efficacy and satisfaction with democracy. In a high-corruption setting, I argue that the highly educated are strongly negatively affected in their institutional attitudes, and thus likely to feel dissatisfied with the way democracy works and disempowered with regard to formal political institutions. At the same time, self-regarding attitudes are not directly connected to the institutional environment, and it will hence often be the case that the highly educated in a low-QoG environment at the same time feel politically competent (positive self-regarding attitudes), but have low trust in formal institutions (negative institutional attitudes).

The second part of the argument considers the implications that this has for political participation. Given their positive self-regarding attitudes, the highly educated will still seek to voice their discontent in high-corruption contexts (Botero et al. 2013). However, given their sense of resignation with regard to formal political institutions (Bauhr and Grimes 2014), the educated will choose a mode of participation that they perceive to be effective (Scartascini and Tommasi 2012). Under weak and corrupt institutions, this means de-emphasizing formal political participation (like voting) and resorting to more unconventional, non-institutionalized means of participation (like protests and demonstrations) (Machado et al. 2011).

Paper 2 tests the empirical implications of this argument by using data from the International Social Survey Program (ISSP), covering 31 democratic countries. Using several different measures of corruption and a range of different modeling techniques, the results show that while the relationship between education and all different measures of political attitudes is positive and strong in contexts with low corruption, the strength of the relationship diminishes dramatically in high-corruption contexts, to the point where it even becomes negative in some cases. With regard to political participation, the results show a strong and positive relationship between education and all kinds of political participation in contexts with high-quality institutions. In low-QoG settings, on the other hand, the strong and positive association between education and voter turnout that has been highlighted in the literature is absent, while the relationship between education and non-institutionalized forms of participation is still significant and strongly positive. The results are hence consistent with the theoretical argument laid out in the paper. 
Building and expanding on the work of Hakhverdian and Mayne (2012), the paper contributes by tying together several research literatures and by providing a more comprehensive argument about how we should understand the relationship between education and political attitudes and behavior in contexts with different institutional quality. By suggesting a framework for thinking about the complex interrelationship between variables like education, corruption, institutional trust, and political participation, while also using new data to explore the argument, the contribution is both theoretical and empirical.

\subsection{Paper 3. The Lesser Evil? Corruption Voting and the Impor- tance of Clean Alternatives}

The third paper in the dissertation (Agerberg (2019b)) starts out from the central question in the literature on corruption voting: why do corrupt politicians get reelected? The question is closely related to the third sub-question in the dissertation; when do citizens punish politicians for involvement with corruption? The general observation that voters do not always 'throw the rascals out' have puzzled researchers for years (De Vries and Solaz 2017). Several different explanations have been suggested, most of which are reviewed in the section on corruption voting above. However, I argue that one critical aspect of corruption voting is understudied, namely the role of clean political alternatives.

Studies show that citizens have a very strong distaste for corruption and a clear preference for clean government, even in societies where corruption is widespread (Karklins 2005; Persson et al. 2013). Therefore, a simple but crucial question to ask for the voter deciding whether to vote for a political candidate accused of corruption is: what are the alternatives? Is there a clean alternative to vote for? Importantly, the decision to vote for a candidate is a decision to choose this candidate over other available political alternatives and over the option to abstain. This important fact has not been sufficiently considered in previous research designs studying corruption voting.

In the paper I develop three hypotheses related to the question of corruption voting and the role of political alternatives. First, I argue that we should expect voters to overwhelmingly punish a corrupt candidate when a clean and credible alternative is available. This is in line with voters' strong anti-corruption preference and consistent with both retrospective and prospective models of political accountability (Ashworth 2012). Second, drawing upon the work of Pãvao $(2015,2018)$, I hypothesize that the lack of a clean political alternative should increase voters' propensity to select a corrupt candidate. In a situation where all political alternatives are viewed as corrupt, other considerations will become more salient, and many voters will hence be willing to consider the 'least bad' political alternative (De Vries 
and Solaz 2017). Third, in the latter situation, other parts of the electorate will feel such a strong aversion to corruption that they will choose to abstain. As noted earlier, the link between corruption and low voter turnout is a well-established finding in the literature (e.g. Stockemer et al. 2013).

The paper deploys an experimental design to test these hypotheses empirically. By using a version of a 'conjoint experiment' (Hainmueller et al. 2014), the study models the three options that are available to a voter when their preferred candidate is accused of corruption: sticking with the candidate, switching to another political alternative, or abstaining. The experiment was fielded in Spain to over 2000 respondents. In the experiment the respondent faces a situation where he or she has to choose between two candidates running for city mayor, each with six different randomly selected traits and attributes. The study (randomly) puts a respondent in a situation where either both candidates are clean, a situation where one of the candidates is accused of corruption, or a situation where both candidates are described as corrupt. In each specific situation the respondent has the alternative to choose to 'not vote'.

The results from the experiment suggest that voters do punish political corruption when a clean alternative exists, even when the corrupt candidate is very appealing in other respects. This finding goes partly against studies claiming that voters are willing to accept corruption if they get things like representation or policy in exchange (e.g. Rundquist et al. 1977). On the other hand, the results show that while voters in general are prone to punish corruption, they tend to vote for the 'least bad alternative' (one of the corrupt politicians) to a relatively high degree when both available candidates are corrupt - even when given a convenient exit option in the form of a 'not vote' alternative. Finally, and consistent with the third hypothesis, the results show that both candidates being corrupt is also a strong predictor of voting abstention.

The main contribution of paper 3 is the novel design that allows me to focus on the previously understudied question of how the available political alternatives play into voters' punishment of corruption. While voters are very prone to punish corruption when a clean alternative exists, the absence of such an alternative leads some voters to become significantly more willing to show loyalty to a corrupt candidate. This is consistent with models emphasizing the increased salience of other dimensions in such a situation (De Vries and Solaz 2017; Pãvao 2018) and citizens' increased tolerance of corruption in high-corruption environments (Corbacho et al. 2016). The paper further discusses how these results can help us understand corruption voting in general, when corruption can be expected to be an important electoral question, and why some societies seem to be stuck in a high-corruption equilibrium (Klasnja et al. 2017). 


\section{Conclusions}

This dissertation centers on the overarching question how does corruption/QoG affect citizens' political attitudes and behavior? Given the extent of the problem with poor QoG in democracies around the world, and given the significance citizens attribute to the issue, I have argued that this question is an important and under-researched topic in political science. Based on my reading of previous research I took three themes in the literature as my point of departure for understanding how QoG influences citizens' political attitudes and behavior. The themes are, to reiterate: (1) corruption is something that people are deeply concerned about, (2) corruption and QoG shape the relationship between the individual and the state, (3) corruption and QoG affect citizens' belief about the capacity of the democratic state. This suggests a model - resembling David Easton's model of the political system (Easton 1953) - where political output feeds back into the input side of politics, but where this feedback mechanism is moderated by the institutional quality.

This reading of the previous research literature initially paints a negative picture of the political life of citizens in settings with low QoG. The picture is largely consistent with the findings of Almond and Verba (1963) from almost 60 years ago, where the authors describe the citizens of highly corrupt societies as cynical, resigned, and 'parochial'. In this sense, citizens in such societies can be expected to have low political trust and low rates of political participation. The results from the three different research papers in this dissertation partly support this picture. Paper 1 shows how citizens experiencing poorly working public institutions can turn away from the traditional political establishment and instead approach more radical populist alternatives. Low trust and confidence in political institutions make these citizens especially susceptible to rhetoric about the deterioration of society and promises of an overturn of the traditional political system. Paper 2 shows, even more clearly, how a high-corruption setting can induce resignation with regard to formal political institutions, even for citizens usually thought of as the most prone to participate in politics. In line with this, paper 3 provides evidence that citizens, despite having a strong preference for clean government, can become more accepting of corruption when they see that the whole system consists of corrupt actors.

While these findings are in line with the previous literature they also constitute a valuable contribution. By going beyond the focus on corruption and vote participation paper 1 provides new theoretical and empirical insights into how poor quality of government not only might affect the decision to participate but also who to support. While there is still much to be said on the topic, this opens up a clear avenue for future research on how corruption shapes political preferences. Paper 2 shows that the positive relationship between education 
and different individual-level political variables, often described as one of the most consistent relationship in political science, is less stable than previously thought. Paper 3 provides a first experimental test of the notion that a political context permeated by corruption can make voters more tolerant of corruption (e.g. Pãvao (2018)).

At the same time, the results also offer a counter-image to the kind of bleak picture described above, often found in previous research on QoG and political attitudes and participation. The three studies in the dissertation show that voters are reacting to the political and institutional environment and adjusting their political behavior accordingly. On the one hand, paper 1 describes dissatisfied and distrusting voters protesting against a corrupt system. On the other hand, the paper describes voters turning towards parties that politicize questions that they care about. In this sense, it is also a story about accountability, where voters turn away from traditional political actors that they view as incapable of dealing with the problems that they experience in their day-to-day lives. While paper 2 shows how the educated lose trust in formal political institutions in high-corruption contexts, these citizens are not resigned and disengaged in a general sense. Rather, they look for other, more efficient, ways of expressing themselves politically by instead relying more on non-institutionalized political participation. Maybe the strongest finding in paper 3 is that voters do punish corruption, when given the chance. In fact, I show that respondents are very dismissive of the corrupt candidate, even when this candidate is politically very close to the voter. Only when all political options are described as corrupt do the respondents become more accepting of corruption. This can be viewed as a rational response: when not given the opportunity to put a clean candidate in office, many voters will opt for the lesser evil and choose based on other political dimensions. All else equal, it is arguably better to have a candidate in office that is corrupt but aligns with your policy preferences otherwise, than a candidate that is both corrupt and whose policy agenda is orthogonal to your political ideals. These are hence also examples of voters showing agency in difficult situations.

I think this is an important contribution to the previous research literature, depicting a more nuanced and complex picture of voters and political actors in democracies where corruption is widespread. While corruption undoubtedly has many adverse effects on people's political engagement and trust in political institutions, citizens are by no means only passive spectators in such settings. Given the strong distaste people around the world show for corruption, and given the importance people place on the issue, this conclusion - sometimes too strongly emphasized in previous research - would be too pessimistic. Rather, citizens often show agency and a strong will to change the system, even though this is undoubtedly an uphill battle. In a corrupt system the risk is that people start viewing corruption as the normal state of affairs. Under these conditions, corruption will not be a salient political 
issue for most voters. What is needed in these contexts is some event that disturbs the status quo. This can be a wave of protests, a new political actor - like a populist party politicizing corruption -, or a politician that manages to portray him or herself as the noncorrupt alternative. When this occurs, voters show very low tolerance for corruption and are willing to use their political power to demand change.

This has implications for politicians and political parties: the results in the dissertation suggest that anti-corruption policies and clean government agendas can be viable ways to attract political support. For instance, when a politician can credibly present him or herself as a clean alternative, voters are very likely to view this favorably. However, as noted in paper 3, this is easier said than done in a context where corruption is very widespread and people's default belief is that most (if not all) political actors are corrupt (Klasnja et al. 2017).

The dissertation also has important limitations. As discussed above, measuring corruption is notoriously difficult and each specific measure has its own specific limitations. We know relatively little about exactly what existing measures are capturing. Countrylevel measures, like CPI, are in general compilations of data from many different sources. Individual-level measures often try to capture a respondent's perception of corruption with a limited number of more or less specific survey questions. It is also not obvious exactly how stated behavior in survey experiment (paper 3) corresponds to real-world behavior (this issue is further discussed in the paper). Overall, this makes it hard to know to what extent these measures actually capture the theoretical construct corruption and to what extent these different measures are comparable across societies. My strategy in this dissertation has been to admit that all measures of corruption are imperfect, and instead try to use many different measures that when taken together say something useful about the overall concept. Still, the fact that one of the main variables in the dissertation is hard to capture empirically is unsatisfying and definitely introduces uncertainty into the studies.

Given the difficulties in measuring the presence of corruption in the first place, it is also a considerable challenge to quantify the causal effect of corruption in different situations. Most existing studies on corruption simply do not have a convincing way of doing this. I have argued that much of this research still can be valuable and important. The first two papers in the dissertation fall mostly into this category of research, where a precise estimate of a causal effect is not the main goal. I argue that we need to understand the overarching patterns in the data to be able to develop theories and to provide a first empirical test of different hypotheses. Yet, to be able to uncover causal relationships - the kind of relationships that most interesting theories in political science ultimately are about - we need to complement these studies with studies based on stronger research designs that put less emphasis on 
statistical modeling and more emphasis on finding plausible exogenous variation in our main independent variable (Rubin 2008). As discussed earlier, I think survey experiments is one way in which research on corruption and politics can approach this problem. Recent examples in the area that use other innovative designs to quantity causal effects include Klasnja (2015) and Bobonis et al. (2016), relying on quasi-experimental designs, and Corbacho et al. (2016) and Olken (2007), relying on field experiments.

Despite these limitations, I consider the dissertation a valuable contribution that opens up several avenues for future research. The results suggest that people in low-QoG societies despite the pacifying effect of corruption - under certain conditions will mobilize and demand change. For instance, paper 3 shows that voters are prone to hold corrupt politicians accountable when they perceive that they have a clean and credible political alternative. Increased knowledge about questions like these will help anti-corruption organizations to identify when a specific message will resonate with the public, and will also help political parties to assess when politicizing corruption can be an effective electoral strategy. Further exploring when and why people in some situations mobilize politically in corrupt societies should be one of the main tasks for future research. Another area of research, where much is still to be done, is research considering how citizens react politically to different types of corruption. This dissertation mainly focuses on two broad categories of corruption: personal experience with bureaucratic corruption, and political corruption scandals. These are obviously heterogeneous categories that each contain many different sub-categories of corruption. Exploring these sub-categories of corruption can help researchers develop more specific theories about citizens' political reactions to corruption. For instance, do citizens distinguish between a bribe paid to a doctor and a bribe paid to get an unjustified advantage (for example paying a bribe to be able to bend the rules when starting a new business)? ${ }^{12}$ To answer questions like these researchers need to develop more refined measures of corruption that are tailored to a specific end.

Overall, the dissertation shows that there are many important research problems in the intersection of the study of quality of government and the study of political behavior. As noted in the introduction, we have yet only scratched the surface with regard to many of these questions, and many big research gaps are still not addressed. My hope is that this dissertation can pave the way for future research projects and point political scientists in a fruitful direction.

\footnotetext{
${ }^{12}$ For a theoretical discussion on these issues, see Bauhr (2016).
} 


\section{References}

Adsera, A., C. Boix, and M. Payne (2003). "Are You Being Served? Political Accountability and Quality of Government". In: Journal of Law Economics and Organization 19.2, pp. 445-490.

Agerberg, Mattias (2017). "Failed Expectations: Quality of Government and Support for Populist Parties in Europe". In: European Journal of Political Research 56, pp. 578-600.

- (2019a). "The Curse of Knowledge? Education, Corruption, and Politics". In: Political Behavior 41.2, pp. 369-399.

- (2019b). "The Lesser Evil? Corruption Voting and the Importance of Clean Alternatives". In: Comparative Political Studies Forthcoming.

Agnafors, Marcus (2013). "Quality of Government: Toward a More Complex Definition". In: American Political Science Review 107.3, pp. 433-445.

Almond, Gabriel A. and Sidney Verba (1963). The Civic Culture. Princton: Book, Whole.

Anderson, Christopher J. and Yuliya V. Tverdova (2003). "Corruption, Political Allegiances, and Attitudes toward Government in Contemporary Democracies". In: American Journal of Political Science 47.1, pp. 91-109.

Anduiza, Eva, Aina Gallego, and Jordi Munoz (2013). "Turning a Blind Eye: Experimental Evidence of Partisan Bias in Attitudes Toward Corruption". In: Comparative Political Studies 46.12, pp. 1664-1692.

Ashworth, Scott (2012). "Electoral Accountability: Recent Theoretical and Empirical Work". In: Annual Review of Political Science 15, pp. 183-201.

Bäck, Hanna and Axel Hadenius (2008). "Democracy and State Capacity: Exploring a Jshaped Relationship". In: Governance 21.1, pp. 1-24.

Bågenholm, Andreas (2013). "Throwing the Rascals Out? The Electoral Effects of Corruption Allegations and Corruption Scandals in Europe 1981-2011". In: Crime, Law and Social Change 60.5, pp. 595-609.

Bakker, Ryan et al. (2015). 2014 Chapel Hill Expert Survey. Chapel Hill, NC: University of North Carolina, Chapel Hill.

Bardhan, Pranab (1997). "Corruption and Development: A Review of Issues". In: Journal of Economic Literature 35.3, pp. 1320-1346.

Bauhr, Monika (2016). "Need or Greed? Conditions for Collective Action against Corruption". In: Governance 30.4, pp. 561-581.

Bauhr, Monika and Marcia Grimes (2014). "Indignation or Resignation: The Implications of Transparency for Societal Accountability". In: Governance 27.2, pp. 291-320. 
Berinsky, A. J., G. A. Huber, and G. S. Lenz (2012). "Evaluating Online Labor Markets for Experimental Research: Amazon.com's Mechanical Turk." In: Political Analysis 20, pp. 351-368.

Blais, Andre (2006). "What Affects Voter Turnout?" In: Annual Review of Political Science 9, pp. $111-125$.

Bobonis, Gustavo J., Luis R. Camara Fuertes, and Rainer Schwabe (2016). "Monitoring Corruptible Politicians". In: American Economic Review 106.8, pp. 2371-2405.

Botero, J., A. Ponce, and A. Shleifer (2013). "Education, Complaints, and Accountability". In: Journal of Law and Economics 56.4, pp. 959-996.

Burlacu, Diana (2018). "Corruption and Ideological Voting". In: British Journal of Political Science Forthcoming, pp. 1-22.

Campbell, Angus et al. (1960). The American Voter. New York: Wiley.

Chang, Eric C. C., Miriam A. Golden, and Seth J. Hill (2010). "Legislative Malfeasance and Political Accountability". In: World Politics 62.2, pp. 177-220.

Charron, Nicholas and Victor Lapuente (2010). "Does Democracy Produce Quality of Government?" In: European Journal of Political Research 49.4, pp. 443-470.

Charron, Nicholas, Victor Lapuente, and Bo Rothstein (2013). Quality of Government and Corruption from a European Perspective. A Comparative Study of Good Government in EU Regions. Cheltenham UK. Northhampton MA USA: Edward Elgar.

Charron, Nicholas, Lewis Dijkstra, and Victor Lapuente (2014). "Regional Governance Matters: Quality of Government within European Union Member States". In: Regional Studies 48.1, pp. 68-90.

Choi, Eunjung and Jongseok Woo (2010). "Political Corruption, Economic Performance, and Electoral Outcomes: A Cross-national Analysis". In: Contemporary Politics 16.3, pp. 249 262 .

Chong, Alberto et al. (2015). "Does Corruption Information Inspire the Fight or Quash the Hope? A Field Experiment in Mexico on Voter Turnout, Choice, and Party Identification". In: The Journal of Politics 77.1, pp. 55-71.

Coppedge, Michael et al. (2016). V-Dem Country-Year Datatset v6.2. Varieties of Democracy (V-Dem) Project.

Corbacho, Ana et al. (2016). "Corruption as a Self-Fulfilling Prophecy: Evidence from a Survey Experiment in Costa Rica". In: American Journal of Political Science 60.4, pp. 10771092.

Croke, Kevin et al. (2016). "Deliberate Disengagement: How Education Can Decrease Political Participation in Electoral Authoritarian Regimes". In: American Political Science Review 110.3, pp. 579-600. 
Curini, Luigi, Willy Jou, and Vincenzo Memoli (2012). "Satisfaction with Democracy and the Winner/Loser Debate: The Role of Policy Preferences and Past Experience". In: British Journal of Political Science 42.2, pp. 241-261.

Dahlberg, Stefan and Sören Holmberg (2014). "Democracy and Bureaucracy: How their Quality Matters for Popular Satisfaction". In: West European Politics 37.3, pp. 515-537.

Dahlberg, Stefan and Maria Solevid (2016). "Does Corruption Suppress Voter Turnout?" In: Journal of Elections, Public Opinion and Parties 26.4, pp. 489-510.

Dahlberg, Stefan, Jonas Linde, and Sören Holmberg (2015). "Democratic Discontent in Old and New Democracies: Assessing the Importance of Democratic Input and Governmental Output". In: Political Studies 63.1, pp. 18-37.

De Sousa, Luís and Marcelo Moriconi (2013). "Why Voters do not Throw the Rascals Out? A Conceptual Framework for Analysing Electoral Punishment of Corruption". In: Crime, Law and Social Change 60.5, pp. 471-502.

De Vries, Catherine E. and Hector Solaz (2017). "The Electoral Consequences of Corruption". In: Annual Review of Political Science 20, pp. 391-408.

Dunning, Thad et al. (2019). "Voter Information Campaigns and Political Accountability: Cumulative Findings from a Preregistered Meta-analysis of Coordinated Trials". In: Science Advances 5, pp. 385-400.

Easton, David (1953). The Political System: An Inquiry into the State of Political Science. New York: Alfred A. Knopf, Inc.

- (1975). "A Re-assessment of the Concept of Political Support". In: British Journal of Political Science 5.4, pp. 435-457.

Escaleras, Monica, Peter T. Calcagno, and William F. Shughart (2012). "Corruption and Voter Participation: Evidence from the US States". In: Public Finance Review 40.6, pp. 789-815.

Eurobarometer (2014). Special Eurobarometer 397: Corruption. Tech. rep. Conducted by TNS Opinion \& Social at the request of the European Commission.

Ezrow, Lawrence and Georgios Xezonakis (2014). "Satisfaction with Democracy and Voter Turnout: A Temporal Perspective". In: Party Politics 22.1, pp. 3-14.

Fernandez-Vazquez, Pablo, Pablo Barbera, and Gonzalo Rivero (2016). "Rooting Out Corruption or Rooting For Corruption? The Heterogeneous Electoral Consequences of Scandals". In: Political Science Research and Methods 4.2, pp. 379-397.

Ferraz, Claudio and Frederico Finan (2008). "Exposing Corrupt Politicians: The Effects of Brazil's Publicly Released Audits on Electoral Outcomes". In: The Quarterly Journal of Economics 123.2, pp. 703-745. 
Fisman, Raymond and Miriam A. Golden (2017). Corruption: What Everyone Needs to Know. New York: Oxford University Press.

Fukuyama, Francis (2013). "What is Governance?" In: Governance 26.3, pp. 347-368.

- (2016). "Governance: What Do We Know, and How Do We Know It?" In: Annual Review of Political Science 19, pp. 89-105.

Gilley, Bruce (2006). "The Determinants of State Legitimacy: Results for 72 Countries". In: International Political Science Review 27.1, pp. 47-71.

Gingerich, Daniel W. (2009). "Corruption and Political Decay: Evidence From Bolivia". In: Quarterly Journal of Political Science 4.1, pp. 1-34.

Global Corruption Barometer (2017). People and Corruption: Citizen's Voices Around the World. Tech. rep. Transparency International.

Gupta, S., H. Davoodi, and R. Alonso-Terme (2007). "Does Corruption Affect Income Inequality and Poverty?" In: Economics of Governance 3.1, pp. 23-45.

Hainmueller, J., D. J. Hopkins, and T. Yamamoto (2014). "Causal Inference in Conjoint Analysis: Understanding Multidimensional Choices via Stated Preference Experiments". In: Political Analysis 22.1, pp. 1-30.

Hakhverdian, Armen and Quinton Mayne (2012). "Institutional Trust, Education, and Corruption: A Micro-Macro Interactive Approach". In: The Journal of Politics 74.3, pp. 739 750 .

Hanley, Seán and Allan Sikk (2016). "Economy, Corruption or Floating Voters? Explaining the Breakthroughs of Anti-establishment Reform Parties in Eastern Europe". In: Party Politics 22.4, pp. 522-533.

Holmberg, Sören and Bo Rothstein (2011). "Dying of Corruption". In: Health Economics, Policy and Law 6.4, pp. 529-547.

Holmberg, Sören, Bo Rothstein, and Naghmeh Nasiritousi (2009). "Quality of Government: What You Get". In: Annual Review of Political Science 12, pp. 135-161.

Holmes, Leslie (2015). Corruption: A Very Short Introduction. Oxford: Oxford University Press.

Hooghe, Marc and Ellen Quintelier (2014). "Political Participation in European Countries: The Effect of Authoritarian Rule, Corruption, Lack of Good Governance and Economic Downturn". In: Comparative European Politics 12.2, pp. 209-232.

Hooghe, Marc, Sofie Marien, and Teun Pauwels (2011). "Where Do Distrusting Voters Turn if There is No Viable Exit or Voice Option? The Impact of Political Trust on Electoral Behaviour in the Belgian Regional Elections of June 2009". In: Government and Opposition 46.2, pp. 245-273. 
Huntington, Samuel (1968). Political Order in Changing Societies. New Haven: Yale University Press.

Jackson, Robert A. (1995). "Clarifying the Relationship Between Education and Turnout". In: American Politics Research 23.3, pp. 279-299.

Karahan, Gökhan R., R. Morris Coats, and William F. Shughart (2006). "Corrupt Political Jurisdictions and Voter Participation". In: Public Choice 126.1/2, pp. 87-106.

Karklins, R. (2005). The System Made Me Do It: Corruption in Post-Communist Societies. Armonk, NY: M.E. Sharpe.

Kaufmann, Daniel, Aart Kraay, and Massimo Mastruzzi (2011). "The Worldwide Governance Indicators: Methodology and Analytical Issues". In: Hague Journal on the Rule of Law 3.2 , pp. $220-246$.

Keefer, Philip (2007). "Clientelism, Credibility, and the Policy Choices of Young Democracies". In: American Journal of Political Science 51.4, pp. 804-821.

Keele, Luke (2015). "The Statistics of Causal Inference: A View from Political Methodology". In: Political Analysis 23, pp. 313-335.

Klasnja, Marko (2015). "Corruption and the Incumbency Disadvantage: Theory and Evidence". In: Journal of Politics 77.4, pp. 928-942.

Klasnja, Marko, Joshua A. Tucker, and Kevin Deegankrause (2016). "Pocketbook vs. Sociotropic Corruption Voting". In: British Journal of Political Science 46.1, pp. 67-94.

Klasnja, Marko, Andrew T. Little, and Joshua A. Tucker (2017). "Political Corruption Traps". In: Political Science Research and Methods Forthcoming.

Konstantinidis, Iannis and Georgios Xezonakis (2013). "Sources of Tolerance Towards Corrupted Politicians in Greece: The Role of Trade-offs and Individual Benefits". In: Crime, Law and Social Change 60.5, pp. 549-563.

Kostadinova, Tatiana (2003). "Voter Turnout Dynamics in Post-communist Europe". In: European Journal of Political Research 42.6, pp. 741-759.

- (2009). "Abstain or Rebel: Corruption Perceptions and Voting in East European Elections". In: Politics and Policy 37.4, pp. 691-714.

Kumlin, Staffan (2004). The Personal and the Political: How Personal Welfare State Experiences Affect Political Trust and Ideology. New York: Palgrave Macmillan.

Machado, Fabiana, Carlos Scartascini, and Mariano Tommasi (2011). "Political Institutions and Street Protests in Latin America". In: The Journal of Conflict Resolution 55.3, pp. 340-365.

Manzetti, Luigi and Carole J. Wilson (2007). "Why do Corrupt Governments Maintain Public Support?" In: Comparative Political Studies 60.5, pp. 471-502. 
Mauro, Paolo (1995). "Corruption and Growth". In: The Quarterly Journal of Economics 110.3, pp. 681-712.

McCann, James A. and Jorge I. Domínguez (1998). "Mexicans React to Electoral Fraud and Political Corruption: An Assessment of Public Opinion and Voting Behavior". In: Electoral Studies 17.4, pp. 483-503.

Mishler, William and Richard Rose (2001). "What Are the Origins of Political Trust?: Testing Institutional and Cultural Theories in Post-communist Societies". In: Comparative Political Studies 34.1, pp. 30-62.

Morgan, Stephen L. and Christopher Winship (2014). Counterfactuals and Causal Inference: Methods and Principles for Social Research. New York: Cambridge University Press.

Munoz, Jordi, Eva Anduiza, and Aina Gallego (2016). "Why Do Voters Forgive Corrupt Mayors? Implicit Exchange, Credibility of Information and Clean Alternatives". In: Local Government Studies 42.4, pp. 1-18.

Olken, Benjamin A. (2007). "Monitoring Corruption: Evidence from a Field Experiment in Indonesia". In: Journal of Political Economy 115.2, pp. 200-249.

Olken, Benjamin A. and Rohini Pande (2007). "Corruption in Developing Countries". In: Annual Review of Economics 4, pp. 479-509.

Pauwels, Teun (2014). Populism in Western Europe: Comparing Belgium, Germany and The Netherlands. London: Routledge.

Pãvao, Nara (2015). "The Failures of Electoral Accountability for Corruption: Brazil and Beyond". PhD thesis. University of Notre Dame.

- (2018). "Corruption as the Only Option: The Limits to Electoral Accountability". In: The Journal of Politics Forthcoming, pp. 1-15.

Persson, Anna, Bo Rothstein, and Jan Teorell (2013). "Why Anticorruption Reforms Fail: Systemic Corruption as a Collective Action Problem". In: Governance 26.3, pp. 449-471.

Persson, Mikael (2015). "Education and Political Participation". In: British Journal of Political Science 45.3, pp. 689-703.

Peters, John G. and Susan Welch (1980). "The Effects of Charges of Corruption on Voting Behavior in Congressional Elections". In: The American Political Science Review 74.3, pp. 697-708.

Rose-Ackerman, Susan (1999). Corruption and Government: Causes, Consequences, and Reform. Cambridge: Cambridge University Press.

- (2017). "What Does "Governance" Mean?" In: Governance 30.1, pp. 23-27.

Rothstein, Bo (2009). "Creating Political Legitimacy: Electoral Democracy Versus Quality of Government". In: American Behavioral Scientist 53.3, pp. 311-330. 
Rothstein, Bo (2011). The Quality of Government: Corruption, Social Trust and Inequality in International Perspective. Chicago and London: The University of Chicago Press.

- (2014). "What is the Opposite of Corruption?" In: Third World Quarterly 35.5, pp. 737752.

Rothstein, Bo and Jan Teorell (2008). "What Is Quality of Government? A Theory of Impartial Government Institutions". In: Governance 21.2, pp. 165-190.

Rothstein, Bo and Aiysha Varraich (2017). Making Sense of Corruption. New York: Cambridge University Press.

Rubin, Donald B. (2008). "For Objective Causal Inference, Design Trumps Analysis". In: The Annals of Applied Statistics 2.3, pp. 808-840.

Rundquist, Barry S., Gerald S. Strom, and John G. Peters (1977). "Corrupt Politicians and Their Electoral Support: Some Experimental Observations". In: The American Political Science Review 71.3, pp. 954-963.

Sartori, Giovanni (1970). "Concept Misformation in Comparative Politics". In: The American Political Science Review 64.4, pp. 1033-1053.

Scartascini, Carlos and Mariano Tommasi (2012). "The Making of Policy: Institutionalized or Not?" In: American Journal of Political Science 56.4, pp. 787-801.

Seligson, Mitchell A. (2002). "The Impact of Corruption on Regime Legitimacy: A Comparative Study of Four Latin American Countries". In: The Journal of Politics 64.2, pp. 408433.

Simpser, A. (2005). "Making Votes Not Count: Strategic Incentives for Electoral Corruption". $\mathrm{PhD}$ thesis.

Solaz, Hector, Catherine E. De Vries, and Roosmarijn A. de Geus (2018). "In-Group Loyalty and the Punishment of Corruption". In: Comparative Political Studies Forthcoming.

Stockemer, Daniel, Bernadette LaMontagne, and Lyle Scruggs (2013). "Bribes and Ballots:

The Impact of Corruption on Voter Turnout in Democracies". In: International Political Science Review 34.1, pp. 74-90.

Sundström, Aksel and Daniel Stockemer (2015). "Regional Variation in Voter Turnout in Europe: The Impact of Corruption Perceptions". In: Electoral Studies 40, pp. 158-169.

Sung, H. E. (2004). "Democracy and Political Corruption: A Cross-national Comparison". In: Crime, Law and Social Change 41.2, pp. 179-193.

The Economist (Dec 14th, 2017). How young Brazilians hope to clean up politics. https: //www . economist . com/news/americas/21732532-first-they-must-get-electedand-old-guard-make-hard-how-young-brazilians-hope.

van Kessel, Stijn (2015). Populist Parties in Europe: Agents of Discontent? Palgrave Macmillan: Palgrave Macmillan. 
Verba, S., K. L. Schlozman, and H. E. Brady (1995). "Beyond Ses: A Resource Model of Political-Participation". In: The American Political Science Review 89.2, pp. 271-294.

Wagner, Alexander F., Friedrich Schneider, and Martin Halla (2009). "The Quality of Institutions and Satisfaction with Democracy in Western Europe: A Panel Analysis". In: European Journal of Political Economy 25.1, pp. 30-41.

Warren, Mark E. (2004). "What Does Corruption Mean in a Democracy?" In: American Journal of Political Science 48.2, pp. 328-343.

- (2006). "Political Corruption as Duplicitous Exclusion". In: PS: Political Science and Politics 39.4, pp. 803-807.

Weitz-Shapiro, Rebecca and Matthew S. Winters (2017). "Can Citizens Discern? Information Credibility, Political Sophistication, and the Punishment of Corruption in Brazil". In: Journal of Politics 79.1, pp. 60-74.

Welch, Susan and John R. Hibbing (1997). "The Effects of Charges of Corruption on Voting Behavior in Congressional Elections, 1982-1990". In: The Journal of Politics 59.1, pp. 226239.

Winters, Matthew S. and Rebecca Weitz-Shapiro (2013). "Lacking Information or Condoning Corruption? When Will Voters Support Corrupt Politicians?" In: Comparative Politics 45.4, pp. 493-504.

- (2016). "Who's in Charge Here? Direct and Indirect Accusations and Voter Punishment of Corruption". In: Political Research Quarterly 69.2, pp. 207-219.

Wolfinger, Raymond E. and Steven J. Rosenstone (1980). Who Votes? New Haven: Yale University Press.

World Economic Forum (2017). Global Shapers Survey. http : / / shaperssurvey . org / static/data/WEF_GSC_Annual_Survey_2017.pdf.

You, J. S. and S. Khagram (2005). "A Comparative Study of Inequality and Corruption". In: American Sociological Review 70.1, pp. 136-157.

Zaller, John (1992). The Nature and Origins of Mass Opinion. Cambridge, UK: Cambridge University Press.

Zechmeister, Elizabeth J. and Daniel Zizumbo-Colunga (2013). "The Varying Political Toll of Concerns About Corruption in Good Versus Bad Economic Times". In: Comparative Political Studies 46.10, pp. 1190-1218. 


\section{Papers I-III}

[1] Agerberg, Mattias (2017). "Failed Expectations: Quality of Government and Support for Populist Parties in Europe". European Journal of Political Research, 56: 578-600.

[2] Agerberg, Mattias (2019). "The Curse of Knowledge? Education, Corruption, and Politics". Political Behavior, 41(2): 369-399.

[3] Agerberg, Mattias (2019). "Corruption Voting and the Importance of Clean Alternatives". Comparative Political Studies, Forthcoming. 